\title{
PENGARUH MODEL PEMBELAJARAN KOOPERATIF TIPE TEAM QUIZ TERHADAP HASIL BELAJAR KOGNITIF PESERTA DIDIK MATERI SISTEM EKSKRESI KELAS XI MIA DI SMA NEGERI 01 MANOKWARI
}

\author{
Nahrul Haya ${ }^{1}$, Aksamina M.Yohanita ${ }^{2}$ Iwan $^{3}$, Syafrizan Ruslan ${ }^{4}$. \\ E-mail: iwan@unipa.ac.id
}

\begin{abstract}
Abstrak: Tujuan penelitian ini untuk mengetahui pengaruh model pembelajaran kooperatif tipe Team Quiz terhadap hasil belajar kognitif peserta didik Materi Sistem Ekskresi kelas XI MIA di SMA Negeri 01 Manokwari. Jenis penelitian ini merupakan penelitian eksperimen semu (Quasi experiment) dengan menggunakan rancangan Non equivalent Control Group Design. Populasi dalam penelitian adalah semua siswa kelas XI MIA di SMA Negeri 01 Manokwari. Teknik pengambilan sampel dengan cara purposive Sampling. Sampel penelitian ini yaitu, kelas XI MIA 3 sebagai kelas eksperimen dan kelas XI MIA I sebagai kelas kontrol. Kelas eksperimen proses pembelajarannya menggunakan model pembelajaran Kooperatif Team Quiz sedangkan kelas kontrol proses pembelajaran dengan cara konvensional. Teknik Pengumpulan data melalui tes hasil belajar kognitif dan bentuk soal pilihan ganda. Hasil analisis data menunjukkan bahwa nilai rata-rata hasil belajar kelas eksperimen adalah 68,88 sedangkan nilai rata-rata kelas kontrol adalah adalah 56,59. Dari hasil Uji $t$ menunjukkan bahwa sig 2-tailed $(0,00<0,025)$. Hal ini menunjukkan bahwa terdapat pengaruh atau perbedaan hasil belajar kognitif peserta didik antara yang diajar dengan menggunakan model pembelajaran kooperatif tipe team quiz dengan yang diajar melalui model pembelajarn konvensional.
\end{abstract}

\section{Kata Kunci: Team Quiz, Sistem Ekskresi}

THE EFFECT OF TEAM QUIZ IN COOPERATIVE LEARNING MODEL TOWARDS THE RESULT COGNITIVE STUDY ON STUDENTS AT EXCRETION SYSTEM MATERIAL CLASS XI MIA AT SMA NEGERI 01 MANOKWARI

\begin{abstract}
The purpose of this study to determine the effect of cooperative learning model type Team Quiz on the cognitive learning outcomes of learners excretion system material Class XI MIA in SMA Negeri 01 Manokwari. This research type is quasi experiment research with non equivalent control group design. The population in the study were all students of class XI MIA in SMA Negeri 01 Manokwari. Sampling technique by purposive sampling. The sample of this research that is, class XI MIA 3 as experiment class and class XI MIA I as control class. Class experimental learning process using Cooperative Team Quiz learning model while the classroom control process of learning in the conventional way. Data collection techniques through cognitive learning outcomes and multiple choice questions. The result of data analysis shows that the mean value of experimental class learning result is 68,88 while the mean of control class is 56,59. From the $\mathrm{T}$ test results show that the sig is 2 -tailed $(0.00$
\end{abstract}

BIOLOGI SEL (VOL7 NO 1 EDISI JAN-JUL 2018 ISSN 2252-858X/E-ISSN 2541-1225) PAGE 29 
$<0.025)$. This shows that there is influence or difference of cognitive learning result of learners between taught by using cooperative learning model team quiz with taught through conventional learning model.

\section{Keywords: Team Quiz, Excretion System}

Pembelajaran merupakan salah satu aspek dari kegiatan manusia secara kompleks yang tidak sepenuhnya bisa dijelaskan atau dijabarkan. Secara lebih simpel, pembelajaran merupakan produk dari interaksi yang berkelanjutan antara pengembangan dan pengalaman. Secara umum, pembelajaran ialah usaha yang dilakukan secara sadar yang dilakukan seorang pendidik untuk membelajarkan peserta didiknya dengan memberikan arahan sesuai dengan sumber-sumber belajar lainnya untuk mencapai sebuah tujuan yang diinginkan (Trianto, 2010:17).

Dalam pelaksanaan kegiatan pembelajaran sains, guru hendaknya memilih dan menggunakan strategi yang melibatkan siswa aktif dalam belajar baik secara mental, fisik maupun sosial. Namun pada kenyataan saat ini secara terus-menerus sampai sekarang, masih berjalan pengajaran sains tradisional yang terbatas pada produk atau fakta-fakta, konsep-konsep teori saja sehingga kurang cocok digunakan untuk mengembangkan keterampilan berpikir siswa karena siswa cenderung hanya menerima materi yang disampaikan guru tanpa harus berpikir untuk menemukan konsep dari suatu pokok bahasan. Untuk menanggulangi kesulitan tersebut disamping penguasaan materi, seorang guru dituntut memiliki keterampilan menyampaikan materi yang akan diberikan. Cara guru menciptakan suasana di kelas sangat pula berpengaruh pada keadaan yang ditampilkan siswa dalam pembelajaran. Apabila guru dapat menciptakan suasana yang membuat siswa termotivasi dan aktif dalam pembelajaran kemungkinan hasil belajar siswa meningkat sesuai dengan yang diharapkan (Hidayah, 2009).

Salah satu usaha guru untuk mengoptimalkan pencapaian tujuan pembelajaran adalah menerapkan model pembelajaran yang tepat. Penggunaan model pembelajaran yang tepat dapat mempengaruhi prestasi belajar peserta didik. Model pembelajaran yang dapat meningkatkan prestasi peserta didik adalah model yang dapat mengaktifkan peserta didik dalam proses pembelajaran. Model pembelajaran yang mengaktifkan peserta didik yakni model yang proses pembelajaran yang tidak hanya berpusat pada guru namun pada proses pembelajaran tersebut melibatkan peserta didik dan berperan aktif.

Proses pembelajaran khususnya materi Biologi dapat dipandang sebagai suatu yang sederhana, namun dapat juga dipandang sebagai sesuatu yang rumit dan kompleks. Karakteristik materi Biologi adalah berupa fakta, pemahaman konsep, proses dari gejala-gejala hidup, dan seluk-beluk yang mempengaruhi hidup interaksi dengan lingkungannya, Sehingga dengan Biologi kita dapat berlatih berpikir secara logis, dan dengan Biologi ilmu pengetahuan lainnya bisa berkembang dengan cepat. Biologi 
timbul karena olah pikir manusia yang berhubungan dengan makhluk hidup, alam dan lingkungan. Sebagian besar siswa menganggap pelajaran Biologi sebagai pelajaran hafalan, sehingga dalam pembelajaran di kelas siswa cenderung mencatat dan mendengarkan penjelasan dari guru. Pemilihan model atau strategi pembelajaran berpengaruh terhadap aktivitas siswa di dalam kelas, aktivitas siswa yang hanya mendengarkan dan mencatat penjelasan dari guru kurang mengembangkan kemampuan berpikir siswa seperti keaktifan bertanya, keaktifan bertanya sangat berpengaruh terhadap hasil pembelajaran (Hasruddin, 2009).

SMA Negeri 01 Manokwari merupakan salah satu sekolah yang telah menerapkan kurikulum 2013. Namun pada kenyataannya, khususnya pelajaran Biologi masih terdapat guru yang mengajar menggunakan model pembelajaran konvensional, dimana hanya guru yang dominan berperan aktif atau suatu pembelajaran yang berpusat kepada guru. Dikarenakan guru yang masih menggunakan model pembelajaran konvensional terdapat berbagai masalah yang ditimbulkan, diantaranya:

1. Peserta didik merasa jenuh atau bosan dengan metode pembelajaran hanya guru yang dominan berperan aktif, sehingga untuk mengurangi kebosanan tersebut, kebanyakan peserta didik tidak memperhatikan kedepan tetapi bercerita dengan teman yang berada disebelahnya atau dengan bermain Handphone (HP).

2. Hilangnya konsentrasi peserta didik juga menjadi salah satu faktor penyebab peserta didik tidak dapat fokus dalam kegiatan pembelajaran, sehingga materi yang diajarkan kurang dipahami dan tidak dimengerti oleh peserta didik sehingga hasil belajar kognitifnya rendah.

Berdasarkan hasil observasi dan wawancara dengan guru mata pelajaran Biologi di SMA Negeri 01 Manokwari, diperoleh bahwa nilai rata-rata penguasaan konsep peserta didik kelas X1 MIA pada mata pelajaran Biologi, umumnya masih dibawah nilai Kriteria Ketuntasan Minimal (KKM) 70. Hal ini dapat mempengaruhi nilai akhir dari proses pembelajaran. Melihat dari permasalahan yang ada di SMA Negeri 01 Manokwari guru diharapkan dapat memecahkan masalah tersebut dengan cara mampu untuk mengembangkan kondisi pembelajaran yang kooperatif, aktif dan efektif serta bervariasai sehingga dapat mengembangkan minat peserta didik. Oleh sebab itu, peneliti ingin menerapkan pengaruh model pembelajaran Kooperatif tipe Team Quiz terhadap hasil belajar kognitif peserta didik.

\section{METOE PENELITIAN}

\section{Lokasi dan Waktu Penelitian}

Penelitian ini dilaksanakan di SMA Negeri 01 Manokwari kelas XI MIA. Waktu penelitian pada bulan Januari-Mei 2017 semester genap tahun ajaran 2016/2017. 


\section{Jenis Penelitian dan Variabel Penelitian}

Jenis penelitian ini adalah penelitian kuantitatif dengan metode penelitian yaitu Quasi Eksperimen (Eksperimen Semu). Tedapat dua variabel yang digunakan pada penelitian ini, yaitu:

a. Variabel Bebas/Independent (X). Variabel bebas adalah variabel yang mempengaruhi terjadinya suatu perubahan yaitu model pembelajaran Kooperatif tipe Team Quiz dan model konvensional.

b. Variabel Terikat/Dependen $(\mathrm{Y})$. Variabel terikat adalah variabel yang dipengaruhi akibat adanya perubahan yaitu hasil belajar kognitif peserta didik.

\section{Populasi dan Sampel}

Populasi pada penelitian ini yaitu seluruh peserta didik kelas XI MIA SMA Negeri 01 Manokwari semester genap tahun ajaran 2016/2017. Sampel pada penelitian terdiri dari dua kelas yaitu Kelas XI MIA 3 sebagai kelas eksperimen yang terdiri dari 27 peserta didik dan kelas XI MIA 1 sebagai kelas kontrol yang terdiri dari 27 peserta didik. Pengambilan sampel dilakukan dengan cara purposive sampling.

\section{Rancangan Penelitian}

Rancangan penelitian yang digunakan dalam penelitian ini yaitu Nonequivalent control group design. Dalam desain penelitian ini memakai dua kelas sebagai kelas kontrol dan kelas eksperimen.

Tabel 1. Desain penelitian eksperimen

\begin{tabular}{llll}
\hline Kelompok & Pretest & Treatment & Posttest \\
\hline Eksperimen & $\mathrm{O}_{1}$ & $\mathrm{X}$ & $\mathrm{O}_{2}$ \\
\hline Kontrol & $\mathrm{O}_{3}$ & - & $\mathrm{O}_{4}$ \\
\hline
\end{tabular}

Sumber: Sugiyono, (2015:79)

Keterangan:

$\mathrm{O}_{1}=$ Pretest kelas eksperimen (diambil sebelum diberikan perlakuan)

$\mathrm{O}_{2}=$ Posttest kelas eksperimen ( diambil setelah diberikan perlakuan )

$\mathrm{X}=$ Perlakuan

$\mathrm{O}_{3}=$ Pretest kelas kontrol

$\mathrm{O}_{4}=$ Posttest kelas control

Instrumen yang digunakan dalam penelitian berupa Rencana Pelaksanaan Pembelajaran (RPP) dan soal pilihan ganda sebanyak 25 sebagai tes kognitif. Untuk menentukan tingkat validitas instrumen disesuaikan dengan kriteria tingkat validitas pada Tabel 2.

Tabel 2. Kriteria tingkat validitas instrumen

\begin{tabular}{cc}
\hline Rata-rata $(\mathrm{M})$ & Kategori \\
\hline $3,5 \leq \mathrm{M} \leq 4$ & Sangat Valid \\
$2,5 \leq \mathrm{M} \leq 3,5$ & Valid \\
$1,5 \leq \mathrm{M} \leq 2,5$ & Kurang Valid \\
$\mathrm{M}<1,5$ & Tidak valid \\
\hline
\end{tabular}

sumber: Hobri (2009) dalam Rohmah (2016)

BIOLOGI SEL (VOL7 NO 1 EDISI JAN-JUL 2018 ISSN 2252-858X/E-ISSN 2541-1225) PAGE 32 
Validitas instrumen divalidasi oleh dosen pembimbing I dan II. Hasil validasi RPP diperoleh hasil validitas 3,7 dinyatakan sangat valid dan hasil validasi soal pilihan ganda diperoleh hasil validitas 3,3 dinyatakan valid dan dapat diterapkan dengan revisi kecil. Reliabilitas dilakukan untuk ketepatan alat evaluasi dalam mengukur. Pengujian reliabilitas berhubungan dengan tingkat kepercayaan terhadap instrumen soal yang digunakan. Untuk menguji realiabilitas tes dalam bentuk pilihan ganda, maka menggunakan rumus KR-21 sebagai berikut (Arikunto, 2015:102):

$$
r 11=\left(\frac{n}{n-1}\right)\left(1-\frac{\mathrm{M}(n-M)}{n \cdot s_{t}^{2}}\right)
$$

Keterangan:

$$
\begin{array}{ll}
\mathrm{r} 11 & =\text { Reliabilitas instrumen } \\
s_{t}^{2} & =\text { Varians total } \\
\mathrm{M} & =\text { Skor rata-rata } \\
\mathrm{n} & =\text { Jumlah butir soal } \\
\text { dengan rumus } s_{t}^{2}=\frac{n \sum x^{2}-\left(\sum x\right)^{2}}{n(n-1)}
\end{array}
$$

Kriteria pengujian reliabilitas tes setelah didapat hasil dari r11 kemudian dibandingkan dengan koefisien reliabilitas.

Tabel 3. Kriteria pengujian reabilitas (koefisien reabilitas)

\begin{tabular}{cl}
\hline Reabilitas & \multicolumn{1}{c}{ Interpretasi } \\
\hline $0,90 \geq$ & Sangat Baik, pada tingkat terbaik tes \\
$0,80-0,90$ & Baik untuk tes di kelas \\
$0,70-0,80$ & Baik untuk tes di kelas. Ada beberapa item yang ditingkatkan \\
& Agak rendah, mungkin ada beberapa item yang ditingkatkan \\
$0,60-0,70$ & Perlu direvisi dengan pertimbangan tertentu \\
$0,50-0,60$ & Kualitas dipertanyakan, perlu direvisi \\
$\leq 0,50$ & \\
\hline
\end{tabular}

Sumber: http://www.washington.edu)

\section{Teknik Pengumpulan.}

Teknik pengumpulan data digunakan untuk mengumpulkan informasi yang diperlukan dalam penelitian ini. Pengumpulan data yang digunakan yaitu:

a. Observasi

Observasi dilakukan untuk mendapatkan infomasi mengenai aktivitas peserta didik dalam suatu pembelajaran untuk mengetahui keadaan awal dari peserta didik.

b. Dokumentasi

Dokumentasi yang dilakukan pada penelitian ini berupa foto kegiatan peserta didik maupun hasil belajar peserta didik. 


\section{c. Wawancara}

Wawancara yang digunakan yaitu wawancara tidak terstruktur dimana untuk mendapatkan informasi keadaan awal sekolah dan kelas berdasarkan keterangan guru mata pelajaran Biologi.

d. Tes

Tes pada penelitian ini digunakan untuk mengetahui hasil perlakuan terhadap sampel. Jenis tes yang digunakan yaitu tes tertulis pilihan ganda dengan jumlah soal sebanyak 25 .

Tes yang digunakan pada penelitian ini adalah:

a. Pretest

Pretest yang digunakan untuk mengetahui keadaan awal peserta didik sebelum diberikan perlakuan.

b. Postest

Postest yang digunakan untuk mengetahui data hasil yang telah diberikan perlakuan.

\section{Teknik Analisis Data}

a. Analisis Deskriptif

Analisis deskriptif dilakukan dengan menguji nilai pada pretes dan postes untuk mendapatkan data rata-rata, skor minimum, skor maksimum dan rentang. Pengujian ini dilakukan dengan menggunakan bantuan software SPSS 20.

\section{b. Analisis Inferensial (Uji Prasyarat)}

Analisis inferensial dibagi menjadi 2 (dua) tahapan yaitu analisis tahap awal dan analisis tahap akhir. Analisis data yang digunakan meliputi uji normalitas dan uji homogenitas sebagai langkah prasyarat dalam melakukan uji hipotesis. Data yang akan dianalisis ad alah data hasil pretes sebelum diberikan perlakuan dan data hasil postes setelah diberikan perlakuan. Menganalisis data yang diperoleh pada penelitian ini menggunakan bantuan software SPSS 20.

\section{c. Uji Normalitas}

Uji normalitas dilakukan untuk mengetahui bahwa data yang digunakan berdistribusi normal atau tidak. Salah satu metode yang digunakan untuk menguji kenormalan data adalah Kolmogorov-Smirnov. Dalam pengujian ini menggunakan bantuan aplikasi software SPSS 20. Untuk mengetahui kenormalan data maka kriteria yang berlaku meliputi:

1) Jika sig (p) $\geq \alpha$, maka sampel berasal dari populasi yang terdistribusi normal

2) Jika sig $(\mathrm{p})<\alpha$, maka sampel tidak berasal dari populasi yang terdistribusi normal. Dimana $\alpha=0,05$ (Nisfianor, 2009)

\section{d. Uji Homogenitas}

Uji homogenitas kesamaan dua varians dilakukan pada penelitian ini untuk mengetaui apakah kedua kelompok yaitu kelas yang menggunakan model pembelajaran

BIOLOGI SEL (VOL7 NO 1 EDISI JAN-JUL 2018 ISSN 2252-858X/E-ISSN 2541-1225) PAGE 34 
Kooperatif tipe Team Quiz (eksperimen) dan kelas yang menggunakan model pembelajaran konvensional (kontrol) memiliki varians yang homogen atau tidak. Uji homogenitas yang digunakan adalah uji levene. Untuk menetapkan homogenitas data maka kriteria yang berlaku meliputi:

1) Jika sig (p) $\geq \alpha$, maka sampel berasal dari varians yang sama

2) Jika sig $(\mathrm{p})<\alpha$, maka sampel tidak berasal dari varians yang sama. Dimana $\alpha=0,05$ (Nisfianor,2009).

\section{e. Hipotesis Statistik}

Uji hipotesis pada penelitian ini dilakukan dengan menggunakan uji-t yang dilakukan dengan uji parametrik. Uji-t ini dapat dilakukan apabila data yang diperoleh homogen dan terdistribusi normal. Bila data yang diperoleh tidak homogen dan terdistribusi normal maka dilakukan uji non-parametrik. Pengujian hipotesis dilakukan dengan bantuan software SPSS 20. Pengujian secara statistik dirumuskan sebagai berikut:

$\mathrm{H}_{0}: \mu_{1}=\mu_{2}$

$\mathrm{H}_{1}: \mu_{1} \neq \mu_{2}$

Keterangan:

1. Jika $\mathrm{H}_{0}$ (diterima), maka tidak terdapat pengaruh dalam penggunaan model pembelajaran Kooperatif tipe Team Quiz terhadap hasil belajar kognitif peserta didik kelas XI MIA pada materi sistem ekskresi.

2. Jika $\mathrm{H}_{1}$ (diterima), maka terdapat pengaruh dalam penggunaan model pembelajaran Kooperatif tipe Team Quiz terhadap hasil belajar kognitif peserta didik kelas XI MIA pada materi sistem ekskresi.

$\mu_{1} \quad$ : Rata-rata hasil belajar kognitif kelompok eksperimen.

$\mu_{2} \quad$ : Rata-rata hasil belajar kognitif kelompok kontrol.

Dengan Kriteria pengujian yang diberikan sebagai berikut :

1. Jika sig $\geq \alpha(0,025) \mathrm{H}_{1}$ ditolak maka $\mathrm{H}_{0}$ diterima (tidak ada pengaruh).

2. Jika sig $<\alpha(0,025) \mathrm{H}_{1}$ diterima maka $\mathrm{H}_{0}$ ditolak (ada pengaruh).

\section{HASIL DAN PEMBAHASAN}

Penelitian ini merupakan penelitian Quasi Experiment yang dilaksanakan di SMA Negeri 01 Manokwari kelas XI MIA, dimana kelas XI MIA 3 sebagai kelas eksperimen dan XI MIA 1 sebagai kelas kontrol.

\section{Deskriptif Data Tahap Awal}

Data yang digunakan untuk melakukan analisis tahap awal adalah data pretes dalam Pelajaran Biologi dengan materi sistem ekskresi, pada kelas eksperimen dan kelas kontrol. Deskriptif hasil penelitian data pretes disajikan pada Tabel 4. 
Tabel 4. Deskriptif Prates Kelas Eksperimen dan Kelas Kontrol

\begin{tabular}{lcc}
\hline \multicolumn{1}{c}{ Deskriptif } & Pretes Eksperimen & Pretes Kontrol \\
\hline Jumlah Peserta Didik & 27 & 27 \\
Minimum & 12 & 12 \\
Maksimum & 52 & 60 \\
Rata-Rata & 32,44 & 35,55 \\
Setandar Deviasi & 10,60237 & 11,27739 \\
Rentang & 40 & 48 \\
\hline
\end{tabular}

Nilai pretes terendah pada kelas eksperimen dan kelas kontrol yaitu 12. Nilai pretes tertinggi kelas eksperimen yaitu 52 dan kelas kontrol yaitu 60 . Rata-rata pretes kelas eksperimen yaitu 32,44 dan kelas kontrol yaitu 35,55. Dengan standar deviasi kelas eksperimen yaitu 10,60237 dan kelas kontrol yaitu 11, 27739 serta rentang untuk kelas eksperimen adalah 40 dan kelas kontrol adalah 48 .

a. Uji Normalitas Pretes

Uji normalitas data pretes dihitung menggunakan Kolmogorov-Smirnov dengan bantuan aplikasi SPSS 20. Kenormalan data dapat dilihat dari nilai signifikan (p). Data memiliki sebaran normal apabila sig $(\mathrm{p}) \geq 0,05$ dan sebaran tidak normal apabila nilai sig $(\mathrm{p})<0,05$. Hasil pengujian normalitas data disajikan pada Tabel 5.

Tabel 5. Uji Normalitas Pretes Kelas Eksperimen dan Kelas Kontrol

\begin{tabular}{llllll}
\hline \multirow{3}{*}{ Hasil Belajar } & \multicolumn{1}{c}{ Kelas } & \multicolumn{3}{c}{ Kolmogorov-Smirnov } & \multirow{2}{*}{ Keterangan } \\
\cline { 2 - 5 } & & Statistik & $\mathrm{df}$ & Sig & \\
\cline { 2 - 5 } & Eksperimen & 0,121 & 27 & 0,200 & Normal \\
& Kontrol & 0,087 & 27 & 0,200 & Normal \\
\hline
\end{tabular}

Berdasarkan Tabel 5 pengujian data menggunakan analisis uji KolmogorovSmirnov nilai kenormalan pretes kelas eksperimen yaitu 0,200 dan nilai kenormalan pretes kelas kontrol yaitu 0,200. Kedua hasil pengujian nilai pretes lebih besar dari 0,05, maka kedua hasil pretes kelas eksperimen dan kelas kontrol berasal dari populasi yang berdistribusi normal.

b. Uji Homogenitas Pretes

Uji homogenitas data pretes juga dihitung menggunakan uji Levene dengan bantuan aplikasi SPSS 20. Data pretes dikatakan homogen apabila nilai signifikan (p) $\geq$ 0,05 dan tidak homogen apabila signifikan $(\mathrm{p})<0,05$. Hasil pengujian normalitas data disajikan pada Tabel 6 .

Tabel 6. Uji Homogenitas Prates Kelas Eksperimen dan Kelas Kontrol

\begin{tabular}{|c|c|c|c|c|c|}
\hline Pretes Eksperimen-kontrol & \multicolumn{4}{|c|}{ Levene } & \multirow{2}{*}{ keterangan } \\
\hline \multirow{2}{*}{ Based of mean } & Statistik & df1 & df2 & Sig & \\
\hline & 0,00 & 1 & 52 & 1,000 & Homogen \\
\hline
\end{tabular}


Berdasarkan Tabel 6 pengujian data menggunakan analisis uji Levene nilai homogenitas kelas eksperimen dan kelas kontrol yaitu 1,000. Kedua hasil pengujian nilai pretes lebih besar dari 0,05, maka kedua hasil pretes kelas eksperimen dan kelas kontrol mempunyai varians yang sama (homogen).

c. Uji Hipotesis (Uji-t) Data Pretes

Uji hipotesis data dilakukan menggunakan bantuan aplikasi SPSS 20. Berdasarkan hasil uji normalitas dan uji homogenitas data pretes kelas eksperimen dan kelas Kontrol maka data memenuhi syarat analisis menggunakan statistik parametrik yaitu uji-t (Tabel 7).

Tabel 7. Hasil Uji Perbedaan Prates Kelas Eksperimen Dan Kelas Kontrol

\begin{tabular}{|c|c|c|c|c|c|}
\hline & & $\mathrm{T}$ & $\mathrm{df}$ & Sig (2-tailed) & Keterangan \\
\hline $\begin{array}{l}\text { Hasil } \\
\text { Belajar }\end{array}$ & $\begin{array}{c}\text { Equal variances } \\
\text { assumed }\end{array}$ & $-1,044$ & 52 & 0.301 & $\begin{array}{l}\text { Tidak ada } \\
\text { perbedaan }\end{array}$ \\
\hline
\end{tabular}

Berdasarkan Tabel 7 diperoleh bahwa hasil uji-t perbedaan pretes kelas eksperimen dan kelas kontrol sebesar 0,301 lebih besar dari 0,025, sehingga $\mathrm{H}_{1}$ ditolak dan $\mathrm{H}_{0}$ diterima, maka data dapat dinyatakan tidak terdapat perbedaan hasil belajar kognitif peserta didik sebelum perlakuan dengan menggunakan model pembelajaran Kooperatif tipe Team Quiz pada kelas eksperimen dan model pembelajaran konvensional pada kelas kontrol.

\section{Deskriptif Data Tahap Akhir}

Data yang digunakan untuk melakukan analisis tahap akhir adalah data postes. Dimana kedua sampel sudah diberikan perlakuan yaitu model pembelajaran Kooperatif tipe Team Quiz pada kelas eksperimen dan model pembelajaran konvensional pada kelas kontrol. Deskriptif hasil penelitian data postes disajikan pada Tabel 8.

Tabel 8. Deskriptif Postes Kelas Eksperimen dan Kelas Kontrol

\begin{tabular}{lcc}
\hline \multicolumn{1}{c}{ Deskriptif } & Postes Eksperimen & Postes Kontrol \\
\hline$\sum$ Peserta Didik & 27 & 27 \\
Minimum & 32 & 32 \\
Maksimum & 84 & 80
\end{tabular}

\begin{tabular}{lcc}
\hline \multicolumn{1}{c}{ Deskriptif } & Postes Eksperimen & Postes Kontrol \\
\hline Rata-Rata & 68,88 & 56,59 \\
Setandar Deviasi & 10,71783 & 12,87591 \\
Rentang & 52 & 48 \\
\hline
\end{tabular}

Nilai postes terendah pada kelas eksperimen dan kelas kontrol yaitu 32. Nilai postes tertinggi kelas eksperimen yaitu 84 dan kelas kontrol yaitu 80. Rata-rata postes kelas eksperimen yaitu 68,88 dan kelas kontrol yaitu 56,59. Dengan standar deviasi kelas eksperimen yaitu 10,71783 dan kelas kontrol yaitu 12,87591 serta rentang untuk kelas eksperimen adalah 52 dan kelas kontrol adalah 48. 
a. Uji Normalitas Postes

Uji normalitas data postes dihitung menggunakan Kolmogorov-Smirnov dengan bantuan aplikasi SPSS 20. Kenormalan data dapat dilihat dari nilai signifikan (p). Data memiliki sebaran normal apabila sig $(\mathrm{p}) \geq 0,05$ dan sebaran tidak normal apabila nilai $\operatorname{sig}(\mathrm{p})<0,05$. Hasil pengujian normalitas data disajikan pada Tabel 9.

Tabel 9. Uji Normalitas Postes Kelas Eksperimen dan Kelas Kontrol

\begin{tabular}{|c|c|c|c|c|c|}
\hline \multirow{4}{*}{ Hasil Belajar } & \multirow{2}{*}{ Kelas } & \multicolumn{3}{|c|}{ Kolmogorov-Semirnov } & \multirow{2}{*}{ Keterangan } \\
\hline & & Statistik & $\mathrm{df}$ & Sig & \\
\hline & Eksperimen & 0,139 & 27 & 0,195 & Normal \\
\hline & Kontrol & 0,074 & 27 & 0,200 & Normal \\
\hline
\end{tabular}

Berdasarkan Tabel 9 nilai normalitas postes kelas eksperimen yaitu 0,195 dan nilai normalitas postes kelas kontrol yaitu 0,200. Kedua hasil pengujian nilai postes lebih besar dari 0,05, maka kedua hasil postes kelas eksperimen dan kelas kontrol berasal dari populasi yang berdistribusi normal.

b. Uji Homogenitas Postes

Uji homogenitas data postes juga dihitung menggunakan uji Levene dengan bantuan aplikasi SPSS 20. Data dikatakan homogen apabila nilai signifikan (p) $\geq 0,05$ dan tidak homogen apabila signifikan $(\mathrm{p})<0,05$. Hasil pengujian normalitas data disajikan pada Tabel 10.

Tabel 10. Uji Homogenitas Postes Kelas Eksperimen dan Kelas Kontrol

\begin{tabular}{ccccccc}
\hline Pretes Eksperimen-kontrol & \multicolumn{5}{c}{ Levene } & \multirow{2}{*}{ Keterangan } \\
Based of mean & Statistik & df1 & df2 & Sig & \\
\cline { 2 - 6 } & 1,460 & 1 & 52 & 0,232 & Homogen \\
\hline
\end{tabular}

Berdasarkan Tabel 10 pengujian data menggunakan analisis uji Levene nilai homogenitas postes kelas eksperimen dan kelas kontrol yaitu 0,232. Kedua hasil pengujian nilai postes lebih besar dari 0,05, maka kedua hasil postes kelas eksperimen dan kelas kontrol mempunyai varians yang sama (homogen).

c. Uji Hipotesis (Uji-t) Data Postes

Uji hipotesis data dilakukan menggunakan bantuan aplikasi SPSS 20. Berdasarkan hasil uji normalitas dan uji homogenitas data postes kelas eksperimen dan kelas Kontrol maka data memenuhi syarat analisis menggunakan statistik parametrik yaitu uji-t (Tabel 11).

Tabel 11. Hasil Uji Perbedaan Postes Kelas Eksperimen dan Kelas Kontrol

\begin{tabular}{cccccc}
\hline & & $\mathrm{T}$ & $\mathrm{df}$ & Sig (2-tailed) & keterangan \\
\cline { 2 - 6 } $\begin{array}{c}\text { Hasil } \\
\text { Belajar }\end{array}$ & $\begin{array}{c}\text { Equal variances } \\
\text { assumed }\end{array}$ & 34,734 & 53 & 0.00 & $\begin{array}{c}\text { Terdapat } \\
\text { perbedaan }\end{array}$ \\
\hline
\end{tabular}

Berdasarkan Tabel 11 diperoleh bahwa hasil uji-t postes kelas eksperimen dan kelas kontrol sebesar 0,00 lebih kecil dari 0,025, sehingga $\mathrm{H}_{1}$ diterima dan $\mathrm{H}_{0}$ ditolak, 
sehingga dapat dinyatakan bahwa terdapat perbedaan antara hasil belajar kognitif peserta didik sesudah perlakuan dengan menggunakan model pembelajaran Kooperatif tipe Team Quiz pada kelas eksperimen dengan hasil belajar menggunakan model pembelajaran konvensional pada kelas kontrol.

\section{Tahap Awal Sebelum dilakukan Proses Pembelajaran}

Tahap awal sebelum dilakukan proses pembelajaran, peserta didik kelas eksperimen dan kelas kontrol diberikan soal pretes untuk menguji kemampuan awal. Pretes ini diberikan sebelum memberikan perlakuan pada sampel.

Hasil pretes tidak terdapat perbedaan hasil belajar pada keadaan awal sebelum sampel diberi perlakuan. Kedua sampel secara statistik memiliki kemampuan yang setara, hal tersebut dikarenakan peserta didik belum belajar materi sistem ekskresi dan juga belum ada perlakuan pada sampel. Hal ini sependapat menurut Sudjana (2009) dalam Rumbekwan (2017) bahwa kemampuan awal lebih rendah daripada kemampuan setelah mendapatkan pembelajaran. Sehingga proses pembelajaran dapat meningkatkan kemampuan untuk memperoleh hasil belajar yang lebih baik. Kemampuan awal peserta didik setara sebelum pembelajaran pada kedua kelas yaitu kelas eksperimen dan kelas kontrol, menunjukkan bahwa peserta didik memiliki konsep yang sama.

\section{Tahap Akhir Sesudah Dilakukan Proses Pembelajaran}

Setelah pemberian perlakuan berupa pembelajaran Kooperatif tipe Team Quiz pada kelas eksperimen dan pembelajaran konvensional pada kelas kontrol, maka kedua sampel diberi postes. Kemudian dilakukan analisis data akhir, dimana pada tahap analisis ini digunakan data postes. Setelah dilakukan pembelajaran (perlakuan) dari kedua kelompok menunjukkan nilai rata-rata kelompok eksperimen dari 32,44 meningkat menjadi 68,88 sedangkan pada kelompok kontrol dari 35,55 menjadi 56,59 maka terdapat perbedaan hasil belajar diakhir pembelajaran. Hasil belajar kelas eksperimen lebih tinggi karena dalam proses pembelajarannya menggunakan model Team Quiz. Model pembelajaran Team Quiz menumbuhkan semangat motivasi untuk berkompetisi, sehingga peserta didik menjadi aktif dan model Team Quiz juga melatih daya ingat untuk berfikir sehingga materi yang berupa hafalan mudah untuk dipahami oleh peserta didik.

\section{Perbedaan Hasil Belajar Kelas Eksperimen dan Kelas Kontrol}

Hasil belajar antara kelas yang diberi perlakuan dengan menggunakan model pembelajaran Kooperatif tipe Team Quiz hasil belajarnya lebih tinggi daripada sampel yang tidak diberi perlakuan dengan menggunakan pembelajaran Kooperatif tipe Team Quiz, hal ini sesuai dengan penelitian yang telah dilakukan oleh Pratiwi, dkk (2016) bahwa Peningkatan hasil belajar antara kelas eksperimen dan kelas kontrol disebabkan karena pada kelas eksperimen sistem pembelajaran menggunakan model Team Quiz. Model pembelajaran Team Quiz yang digunakan pada kelas eksperimen mendorong siswa untuk bekerja sama dalam kelompoknya, sehingga model pembelajaran Team 
Quiz mampu meningkatkan prestasi belajar siswa. Team Quiz menunjukkan bahwa dalam proses pembelajaran menempatkan siswa sebagai pusat kegiatan belajar mengajar (Student Centered Learning), sedangkan guru hanya bertindak sebagai fasilitator, pendamping, serta pembimbing selama proses kegiatan pembelajaran.

Berdasarkan Hasil analisis uji-t secara statistik terdapat perbedaan hasil belajar kelas eksperimen dan kelas kontrol yang ditunjukkan dengan nilai signifikan $(0,00<$ 0,025), disimpulkan bahwa ada pengaruh penggunaan model pembelajaran Kooperatif tipe Team Quiz terhadap hasil belajar kognitif peserta didik pada materi sistem ekskresi kelas XI MIA di SMA Negeri 01 Manokwari. Hal ini sependapat dengan Mardiyanto (2014) bahwa hasil belajar siswa yang menggunakan model Team Quiz memiliki pengaruh terhadap hasil belajar siswa. Hasil belajar siswa kelas eksperimen yang menggunakan model Team Quiz lebih tinggi daripada hasil belajar kelas kontrol yang menggunakan model pembelajaran konvensional. Penelitian yang dilakukan oleh Hilyatun (2009), Aswan dan Syaiful (2006) dalam Wulantika, dkk (2011) bahwa menggunakan model pembelajaran dengan Team Quiz memperoleh hasil pembelajaran begitu memuaskan dan sesuai dengan target yang diinginkan.

\section{KESIMPULAN}

Berdasarkan hasil penelitian, analisis data dan pembahasan, dapat disimpulkan bahwa terdapat pengaruh model Pembelajaran Kooperatif tipe Team Quiz terhadap hasil belajar kognitif peserta didik pada materi sistem ekskresi Kelas XI MIA di SMA Negeri 01 Manokwari.

\section{SARAN}

Berdasarkan hasil penelitian dan kesimpulan, maka saran yang dikemukakan pada penelitian ini adalah:

1. Dalam kegiatan proses belajar mengajar, model pembelajaran yang aktif, kreatif, dan menyenangkan bagi peserta didik dapat diterapkan oleh guru didalam kelas.

2. Model pembelajaran Kooperatif tipe Team Quiz dapat digunakan sebagai salah satu alternatif pada proses pembelajaran Biologi.

3. Bagi peneliti selanjutnya diharapkan dapat melakukan penelitian menggunakan model Kooperatif tipe Team Quiz yang dipadukan dengan model pembelajaran Kooperatif lainnya.

\section{DAFTAR PUSTAKA}

Arikunto, Suharsimi. 2015. Dasar-Dasar Evaluasi Pendidikan. Edisi 2. Jakarta: Bumi Aksara.

Hasruddin. 2009 “Peran Multi Media Dalam Pembelajaran Biologi”. Jurnal Tabularasa, 06(02): 149-160. 
Hidayah, R. 2009. "Pendekatan Struktural TPS dan NHT”. Tesis, Universitas Negeri Surabaya, Mardiyanto, Sigit, dan J.A Pramukanto. "Pengaruh Model Active Learning dengan Model Team Quiz Terhadap Hasil Belajar pada Standar Kompetensi Melakukan Pekerjaan Mekanik Dasar Di SMK Negeri 5 Surabaya". Jurnal Pendidikan Teknik Elektro, 01(03), 2014: 239-244.

Nisfianor, Muhammad. 2009. Pendekatan Statistic Modern. Salemba: Jakarta

Partiwi, W., Yamtinah, S., dan Redjeki, T. 2016: "Penerapan Metode Pembelajran Quiz Team Untuk Meningkatkan Aktivitas dan Prestasi Belajar Siswa Pada Materi Kelarutan dan Hasil Kali Klearutan Di Kelas XI IPA2 SMA Al-Islam 1 Surakarta Tahun Ajaran 2014/2015". Jurnal Pendidikan kimia 1(5), 46-54.

Rumbekwan, Yanto, O. 2017. "Pengaruh Penggunaan Lembar Kerja Siswa (LKS) Berbasis Cooperative Script Terhadap Hasil Belajar Biologi Materi Gerak Dan Hama Tumbuhan di Kelas VIII SMP Negeri 11 Manokwari” Skripsi, Universitas Papua Manokwari

Sugiyono. 2015. Metode Penelitian Kuantitatif, Kualitatif dan $R \& D$. Bandung: Alfabeta Trianto. 2010. Mendesain Model Pembelajaran Inovatif-Progresif. Komsep, Landasan dan Implementasi pada Kurikulum Tingkat Satuan Pendidikan. Jakarta: Rencana,

Wulantika, Alyuni, Harlita dan Joko Arianto. Pengaruh Strategi Pembelajaran Tipe Team Quiz Terhadap Hasil Belajar Biologi Ditinjau Dari Keaktifan Bertanya Pada Siswa SMA Negeri 1 Karangpandan Tahun Pelajaran 2011/2012. Jurnal Pendidikan Biologi, 3(3), 2011: 1-11. 